\title{
The Experimental Study of the Effectiveness of Teaching Speaking by Using Cartoon in the Fifth Year Students of Islamic Elementary School
}

\author{
Uswatun Hasanah \\ English Department of Educational Faculty \\ State Islamic Studies Institute (STAIN) Salatiga \\ Uswatun84@gmail.com
}

\begin{abstract}
This research was carried out to find out how far the achievement of speaking English lesson by using cartoon and a significant difference of the students speaking ability between the students taught by using cartoon media and those taught without using cartoon media. The research was conducted at Islamic Elementary School (Madrasah Ibtidaiyah) Lancar, Wonosobo, Central Java, Indonesia. The objects of the research were the fifth year students. This is quantitative research. Technique of sampling in this research used classified random sampling. The result of the research is the score of the post-test from the experiment group is higher $(7,68)$ than the score of the post-test from control group $(6,95)$. Therefore, the writer might conclude that using of cartoon media proved better result in speaking skill than students who are taught without using cartoon media. It means that there is significant difference of the students speaking skill between those using cartoon media and those who do not use cartoon in teaching speaking. Also, there is a significant contribution of using cartoon in teaching speaking.
\end{abstract}

Keywords: Effectiveness, Speaking, Cartoon Media, Teaching Speaking through Cartoon for Elementary School Students

\begin{abstract}
Abstrak
Penelitian ini dilakukan untuk mengetahui sejauh mana pencapaian pelajaran berbicara bahasa Inggris dengan media kartun dan perbedaan yang signifikan dari kemampuan berbicara antara siswa yang diajar dengan menggunakan media kartun dengan siswa yang tidak diajar menggunakan media kartun. Penelitian ini dilakukan di Madrasah Ibtidaiyah Lancar, Wonosobo, Jawa Tengah, Indonesia. Objek penelitian ini adalah siswa kelas lima. Ini adalah penelitian kuantitatif dengan teknik sampling yang digunakan adalah random
\end{abstract}

REGISTER, VOL. 2, No. 1, JUNE 2009 
sampling. Hasil dari penelitian ini menunjukkan skor post test dari kelas eksperimen lebih tinggi $(7,68)$ daripada skor post test dari kelas kontrol $(6,95)$. Sehingga, peneliti bisa menyimpulkan bahwa penggunaan media kartun membuktikan hasil yang lebih baik jika diterapkan dalam pengajaran ketrampilan berbicara bahasa Inggris.

Hal ini berarti ada perbedaan yang signifikan dari kemampuan berbicara antara siswa yang diajar dengan menggunakan media kartun dengan siswa yang tidak diajar menggunakan media kartun. Selain itu, penggunaan media kartun dalam pengajaran berbicara bahasa Inggris merupakan satu kontribusi yang penting.

Kata Kunci: Keefektifan, Berbicara, Media Kartun, Pengajaran Bahasa Inggris Dengan Kartun untuk Siswa Sekolah Dasar

\section{Introduction}

The primary task of a teacher is educating. Education is an activity done consciously to develop students' potential and change self quality from low quality to the high one. Many problems are faced in teaching learning process especially for teachers who are responsible to make students understand the materials, to control the classroom, so the students enjoy, happy in learning process and success in their study. Most of the English teachers use the traditional method in teaching speaking. They usually read the new words or write them on the blackboard and ask the students to be able to memorize the words as soon as possible and as many as possible as well. The problems which commonly appears is that the students forget the words which they have just learned easily and get bored with what they are reading in the reading materials. For these reasons above, good teachers who have high capability in teaching learning process are needed. Teachers should have a good method. A certain technique is very important. It is better for the teachers to be creative in preparing and applying it. The technique here may use visual aids, especially in teaching speaking. Visual aids are available in 
many forms, for example pictures, cards, games, puzzle, etc. In this study, the writer observes the teaching speaking by using cartoon. Cartoon is part of visual media. According to Arsyad (1997:89), visual media has an important role in teaching learning process. By using cartoon, the teacher would be able to motivate them to learn and pay deep attention to the presentable materials by the teachers, so the students will not be tedious.

Regarding the explanation above, the writer would like to know the influence of using cartoon as the media to the students' speaking skill. The writer chooses the students' speaking skill because it is suitable with Indonesian government which determines English as a compulsory subject which must be taught since elementary school until senior high school.

To make the students speak English easily, the writer uses cartoon media. The students in this research are the fifth years students of Islamic Elementary School Lancar who are still suitable to use cartoon media, as Zenger (1982 : 83) said that cartoon are alright for elementary school age pupil or young people. By using media may make students more interested in learning English. Thus, they have a good quality in English speaking, especially the students in Islamic Elementary School Lancar.

Based on the problems above, the objectives of research can be specified as follows: (1) To find out how far the achievement of speaking English lesson by using cartoon (2) To find out a significant difference of the students speaking ability between the students taught by using cartoon media and those taught without using cartoon media.

The writer also presented the research hypothesis which was stated as follows:

" There is a significant difference in teaching speaking between students who are taught by using carton and those are not taught by using cartoon of the fifth year students of Islamic Elementary School Lancar.”

REGISTER, VOL. 2, No. 1, JUNE 2009 


\section{Speaking}

'Speaking' as language skill is a primary skill. The skill holds a crucial part in human life from the beginning to build the relationship of two directions in giving and receiving information. Speaking is method of transcribing the sounds of language. The sounds of language can be described in three principal ways: according to (1) their composition, (2) their distribution and (3) their function (Dinneen, 1967:20). People express their ideas, emotions and desires through speech by forming sounds and the human being forms sounds in order to express himself and to communicate with others.

Speaking cannot be separated from listening. It can be seen when a speaker says something, she/he needs to listen the other speaker in order to get interaction between speaker and listener. Tarigan (1986 : 86) stated, "Speaking is an interactive process and one which difficult to associate from listening in many ways."

Speaking is developing after listening skill in children's life, for example: in their first two months babies just listen to the people around them. They can repeat some of words that often used. This statement is supported in interacting with others, children hear many well formed sentences. From listening to adults and others, they extract rules about the language they heard. It is emphasized by K. Jarome, who mentioned, "They very quickly absorb rules of structure and begin to use them."

From the statement above, the writer concludes that speaking is the expression of ideas, emotions and desires through speech by forming sound or oral interactions directly which give information to other people. If someone wants to speak, he/she need to hear. Speaking skill cannot be separated with listening skill. In teaching and learning process, the principles 
above can be applied. This can be applied through the use of words as words in cartoon script.

\section{Media}

Oxford defines media as mass communications, such as television, radio, newspaper, etc. Instructional media includes a wide range of materials, equipment, and technique: chalkboard, bulletin, filmstrips, slides, cartoon, TV, models, demonstrations, charts, maps, book, and combination of these.

The audiovisual aids can be interpreted as any substances which play an important role in teaching and learning processes. They help the students master the material more interestingly. Audiovisual aids as one of the media are not new things in the instructional world. Things such as television and video compact disk are often found in the teaching learning process.

In addition, there are several functions of media in general and their contributions to language learning. Those include:

a. The instructional can be more interesting

Visual aids can attract the students' interest, especially those of English learners. If they are interested, they will give much attention to what is being taught or discussed. This can lead to an interesting language learning process.

b. Learning becomes more interactive

Many activities can be created through applying visual aids in the teaching, for example: watching cartoon on television. This activity is relatively more interesting than the activity of listening or writing the teacher's explanation.

c. The quality of learning can be improved 
If there is a good preparation of using visual aids, it will be possible for teacher to create a good language which students' participation is dominant. As a result, the students' knowledge and skill can be improved.

d. The positive attitude of students toward what they are learning and to the learning process itself can be enhanced.

\section{Cartoon}

K.Z Sharon (1977: 82) said that 'Cartoon' is humorous pictorial drawing which utilize sarcasm, ridicule, and exaggeration about a person, action and subject of current interest. Its main purposes are to attract attention and to motivate in a concise manner. Cartoon is one of the media for learning. Cartoon is usually found in newspapers, magazines, or other publication and takes them to class for discussion purposes.

For pupils producing their own cartoons, many different materials can be employed. The cartoons could be drawn, paint brushes and chalk. Cartoon can also be used for political matters, for example when cartoonist wants to satirize politician, he usually draws the politician picture in newspaper or magazine. Sharon and Weldon (1977: 57) states, "Cartoon can be used to emphasize certain points in reading material or to exaggerate something about a popular political person then some are merely for fun“".

\section{The Advantages of Cartoon Media}

As the teaching and learning media, cartoon has several advantages as follows:

a. The students pay more attention and interested to study.

b. Helps in understanding a message faster than by reading about the topic in an article.

c. Aids in comprehending an overall concept by breaking it down into simple form.

REGISTER, VOL. 2, No. 1, JUNE 2009 
d. Teaches that cartoons can be biased and that pupils need to read carefully and critically.

e. Arouses emotions and can affect attitudes and behaviors.

f. Can be drawn by a student showing what he has learned from a lesson.

g. Cartoon can stimulate and motivate students to become observant and express them.

\section{Teaching Speaking through Cartoon for Elementary School Students}

Teaching cannot be defined apart from learning. In teaching speaking, to satisfy the practical demands of education, theories of learning must be "stood on the other hand" so as to yield theories of teaching.

Language learning is an active process. It is not enough for learners just to have the necessary knowledge to make things meaningful, they must also use that knowledge. However, it is important to be cleared of what we mean by the term active in the teaching of speaking skill, we are engaged in two processes:

1. Forging an instrument

2. Giving the students practice in its use (Rivers, 1981: 190)

Most children like cartoon. They like cartoon because it is fun. It is their favorite amusement during late childhood (late childhood extends from the age of six to the time individual become sexually mature).

In reading, children like to read some books which are related to cartoon. They found it in adult magazine or in newspaper. Children also like to buy and collect some comic books. They keep their pocket money to buy them. In watching television, children like to watch cartoon programs. On Sunday morning they do not want to go out because many televisions broadcast cartoon programs such as Shincan, Donald Duck, Sailor Moon, etc.

REGISTER, VOL. 2, No. 1, JUNE 2009 
Based on the statement above, it can be assumed that most children like to see cartoon. So, cartoon can be used as a visual aid in teaching. Sadiman (1986: 47) stated cartoon has big ability for making an intention. Therefore, it is part of visual aids. Teacher can use cartoon as visual aids. It can help the learner to catch the information in English speaking. The teacher can also make variety by using cartoon. As an example: the teacher can cut cartoon from comic book, comic magazine or newspaper. After cutting, the teacher collects and classifies it based on the topic.

\section{Research Methodology}

The research was conducted at Islamic Elementary School (Madrasah Ibtidaiyah) Lancar, Wonosobo, Central Java, Indonesia. The objects of the research were the fifth year students in the academic year of 2006/2007. This is quantitative research. Technique of sampling in this research used classified random sampling. By this technique, the writer united the objects in population, so all the subjects in this population will be considered same and the objects had the same opportunity to be the sample.

The writer employed two kinds of data collection namely pre-test and post-test. Pre-test was used to know the student master in speaking materials before the teaching-learning process was given. Whereas, the post-test is done after the students got different treatments (group A is taught by using cartoon and group B is taught without using cartoon).

To make the data in this research complete and clear, the writer described the experiment group and the control group as follows:

\begin{tabular}{|c|l|c|}
\hline No. & \multicolumn{1}{|c|}{ Experiment Group } & \multicolumn{1}{c|}{ Control Group } \\
\hline 1. & $\begin{array}{l}\text { Teacher gave the students pre- } \\
\text { test }\end{array}$ & Teacher gave the students pre-test \\
\hline
\end{tabular}




\begin{tabular}{|c|c|c|}
\hline 2. & $\begin{array}{l}\text { Teacher gave the topics of the } \\
\text { lesson, they were: place and } \\
\text { transportation }\end{array}$ & $\begin{array}{l}\text { Teacher gave the topics of the } \\
\text { lesson, they were: place and } \\
\text { transportation }\end{array}$ \\
\hline 3. & $\begin{array}{l}\text { The teacher showed some } \\
\text { cartoons that were related to the } \\
\text { topic (teaching by using } \\
\text { cartoon) }\end{array}$ & $\begin{array}{l}\text { The teacher gave the students } \\
\text { explanation that were related to the } \\
\text { topic (teaching without using } \\
\text { cartoon) }\end{array}$ \\
\hline 4. & $\begin{array}{l}\text { The students gave attention to } \\
\text { the cartoon and read the cartoon, } \\
\text { answered the question from the } \\
\text { teacher. }\end{array}$ & $\begin{array}{l}\text { The students listened the } \\
\text { explanation and answered the } \\
\text { question from the teacher. }\end{array}$ \\
\hline 5. & $\begin{array}{l}\text { The teacher gave students post- } \\
\text { test to evaluate them }\end{array}$ & $\begin{array}{l}\text { The teacher gave students post-test } \\
\text { to evaluate them. }\end{array}$ \\
\hline
\end{tabular}

After all the data are collected, the writer investigates the completeness of the data then will organize the scores taken from test activities and then sum up them.

The step of analyzing data is based on the formula as follows:

$$
t=\frac{M x-M y}{\sqrt{\left(\frac{\sum x 1+\sum x y 1}{N x+N y-2}\right)\left(\frac{1}{N x}+\frac{1}{N y}\right)}}
$$

Explanation:

$\mathrm{t}=$ the result of $\mathrm{t}$-test calculation

$\mathrm{Mx}=$ the average of experiment class' score

$\mathrm{My}=$ the average of control class' score

REGISTER, VOL. 2, No. 1, JUNE 2009 
$\mathrm{x} 1=$ the sum of squared deviation ( $\mathrm{x})$ score of the experiment class

$\mathrm{y} 1=$ the sum of squared deviation (y) score of control class

$\mathrm{Nx}=$ the number of students of the experiment class

$\mathrm{Ny}=$ the number of students of the control class

Then, the result was consulted with t-table. If the calculation is more than or same with $\mathrm{t}$-table, it means that there is a significant difference between the two groups. If the calculation is less than t-table, it means that there is no significant difference between them.

\section{Discussion}

To get the data, the writer used some kinds of test. There are two kinds of test that are needed in this research, they are pre-test and post-test. The pre-test is used to know the student's speaking ability before getting different treatments. The post-test is used to know the result of the experiment. After the pre-test scores of each respondent were found, the average of the score was then calculated.

After getting the pre-test score, the writer used a formula to know whether the difference of both groups was significant or not. Once, the writer found the result, such as the mean of group A is 15,1 and the mean of group $\mathrm{B}$ is 22,37 . From the calculation, the difference of rate between two groups is 1,42 . It is consulted the t-table with $5 \%$ level of significance and the degree of freedom in this research is $42(22+22-2)$. The table of the figure is 2,00 . The calculation shows that t-table is higher than test. It means that there is no significant difference between.

Based on the fact above, the writer continued to carry out the research because the requirement was fulfilled. After the result of the pre-test was carried out, the two groups were given the post test. The result of post-test is 
then calculated using t-test. Finally, the writer found the result that after the post-test the mean of group A is 16,78 and the mean of group B is 12,96 . Both of the result was then consulted to t-table $5 \%$ level of significance. The procedure of drawing a conclusion is there is a significance difference between group A and B. The result of t-table with degree of freedom is 42 $(22+22-2)$ is 2,00 while the result of t-test is 2,92 . It is shown that t-test is higher than t-table. In addition, the percentage of how far the difference of the students' speaking skill between the experiment groups and the control group is $4,98 \%$.

\section{Result of the Research}

The result of the research in this study are the score of the post-test from the experiment group is higher $(7,68)$ than the score of the post-test from control group $(6,95)$. So, based on the above explanation, the writer concluded that using of cartoon media proved better result in speaking skill than students who are taught without using cartoon media.

It means that there is significant difference of the students speaking skill between those using cartoon media and those who do not use cartoon in teaching speaking. And there is a significant contribution of using cartoon in teaching speaking and the difference of the experimental group and controlled group is $4,98 \%$.

\section{Conclusion}

In this study, the control group taught without using cartoon in their speaking activity has lower score than experimental group taught using pictures media in their speaking activity. In the post test, score of the controlled group is 153 with the number of the students are 24 . It means, the 
mean of this group is 6,95. In the post test, the experimental group taught using cartoon media in their speaking activity has better score than controlled group. Score of the experimental group is 169 with the number of the students are 24. It means, the mean of group is 7,68.

There is a significant difference in the result of teaching speaking by using cartoon and without using cartoon. In fact, the result of the different mean between the experiment class and the control class is 2, 92 and there is a significant contribution of using cartoon. The difference of the experimental group and controlled group is $4,98 \%$.

\section{References}

Arif, Sadiman. 1986. Media Pendidikan: Pengertian, Pengembangan dan Pemanfaatannya, Jakarta: PT. Raja Grafindo Persada.

Azhar, Arsyad. 1997. Media Pengajaran. Jakarta: PT. Raja Grafindo Persada.

Djago, Tarigan and HG, Tarigan. 1986. Teknik Pengajaran Ketrampilan Berbahasa. Bandung: Angkasa IKAPI.

Francis, P. Dinneen. 1967. An Introduction to General Linguistics. New York: SN - New York.

Oxford. 1985. Oxford Learner's Pocket Dictionary. New Edition. New York: Oxford University Press.

Paul, H.M., John, J.C. and Jerome, K. 1817. Essentials of Child Development and Personality. New York: Harper and Row.

Sharon, K. Zenger \& Weldon, F. Zenger. 1982. 57 Ways to Teach. LA California: Cresent Publication.

Wilga, M. Rivers. 1981. Teaching Foreign Language Skill. Second Edition. Chicago: The University of Chicago Press. 